\title{
Photocorrosion-Resistant $\mathrm{Sb}_{2} \mathrm{Se}_{3}$ Photocathodes with
}

\section{Earth Abundant $\mathrm{MoS}_{\mathrm{x}}$ Hydrogen Evolution Catalyst}

Rajiv Ramanujam Prabhakar ${ }^{1}$, Wilman Septina ${ }^{1}$, Sebastian Siol ${ }^{2}$, Thomas Moehl ${ }^{1}$, René WickJoliat $^{1}$, and S. David Tilley ${ }^{1 *}$

This document is the accepted manuscript version of the following article: Prabhakar, R. R., Septina, W., Siol, S., Moehl, T., Wick-Joliat, R., \& Tilley, S. D. (2017). Photocorrosion-resistant $\mathrm{Sb} 2 \mathrm{Se} 3$ photocathodes with earth abundant MoSx hydrogen evolution catalyst. Journal of Materials Chemistry A. http://doi.org/10.1039/C7TA08993G

\footnotetext{
Affiliations:

${ }^{1}$ University of Zurich , Zurich , Switzerland

${ }^{2}$ EMPA, Dubendorf, Switzerland
}

*Corresponding author: david.tilley@chem.uzh.ch 


\begin{abstract}
The poor stability of high efficiency photoabsorber materials in aqueous media is one factor holding back the realization of photoelectrochemical (PEC) water splitting for large scale, practical solar fuels generation. Here, we demonstrate that highly efficient thin film $\mathrm{Sb}_{2} \mathrm{Se}_{3}-$ fabricated by a simple, low temperature selenization of electrodeposited $\mathrm{Sb}$-is intrinsically stable towards photocorrosion in strongly acidic media (1 $\mathrm{M} \mathrm{H}_{2} \mathrm{SO}_{4}$ ). Coupling with a photoelectrodeposited $\mathrm{MoS}_{\mathrm{x}}$ hydrogen evolution catalyst gives high photocurrents $\left(5 \mathrm{~mA} \mathrm{~cm}{ }^{-2}\right.$ at $0 \mathrm{~V}$ vs RHE) and high stability without protective layers. A low temperature sulfurization of the $\mathrm{Sb}_{2} \mathrm{Se}_{3}-\mathrm{MoS}_{\mathrm{x}}$ stack dramatically improved the onset potential, resulting in high photocurrent densities up to $\sim 16 \mathrm{~mA} \mathrm{~cm}^{-2}$ at $0 \mathrm{~V}$ vs RHE. The simplicity with which these photocathodes are fabricated, combined with the high photocurrents and stability, make $\mathrm{Sb}_{2} \mathrm{Se}_{3}$ a strong candidate for scalable PEC cells.
\end{abstract}




\section{Introduction}

The direct conversion of solar energy into fuels is an elegant strategy to address the intermittency of solar energy, while sustainably maintaining our fuel-based economy. ${ }^{1}$ One method to generate solar fuels is photoelectrochemical (PEC) water splitting. ${ }^{2}$ Research in PEC water splitting has focused on improving both the efficiency and the stability of the semiconducting materials, which has a large impact on the cost of the resulting hydrogen. ${ }^{3}$ Although crystalline silicon sets the benchmark for solar conversion technology, it requires a large amount of energy and other resources for processing in order to make it highly efficient. ${ }^{4}$ Thus, researchers are searching for new materials that are more easily fabricated while retaining high efficiency. $\mathrm{Sb}_{2} \mathrm{Se}_{3}$ has been gaining importance in the photovoltaic community recently owing to its non-toxicity and Earth abundance along with promising solar cell efficiencies $(6 \%) .{ }^{5,6}$ Although this material has been investigated for solar cell applications, there has thus far been only one report on $\mathrm{Sb}_{2} \mathrm{Se}_{3}$ as a PEC electrode for water splitting. Moon and coworkers showed $\mathrm{H}_{2}$ evolution using $\mathrm{Sb}_{2} \mathrm{Se}_{3}$ nanoneedles, although the photocurrent densities obtained were much smaller than in solar cells $\left(\sim 2 \mathrm{~mA} \mathrm{~cm}^{-2}\right.$ at $0 \mathrm{~V}$ vs $\left.\mathrm{RHE}\right)$, and rather poor stability was observed despite having a $\mathrm{TiO}_{2}$ protection layer $(<20 \mathrm{~min}){ }^{7}$ In addition to a highly efficient and stable photocathode, it is equally important to couple it with a low cost, non-toxic and Earth abundant catalyst. One such promising hydrogen evolution reaction (HER) catalyst is $\mathrm{MoS}_{2}$, with low overpotentials for water reduction. $\mathrm{MoS}_{2}$ has been employed as an $\mathrm{HER}$ catalyst for both $\mathrm{Cu}_{2} \mathrm{O}$ and $\mathrm{GaInP} 2$ photocathodes, and provides comparable PEC performance as with a Pt catalyst. ${ }^{8,9}$ Since $\mathrm{MoS}_{2}$ works efficiently only in strong acid $(\mathrm{pH} 0$ or $\mathrm{pH} 1)$, protective $\mathrm{TiO}_{2}$ overlayers were required to prevent corrosion of the photocathodes. ${ }^{10}$ 
In this work, we demonstrate that $\mathrm{Sb}_{2} \mathrm{Se}_{3}$ is resistant to photocorrosion without protective layers, and high photocurrent densities are obtained when coupled with an Earth abundant HER catalyst $\left(\mathrm{MoS}_{\mathrm{x}}\right)$. By sulfurizing the $\mathrm{Sb}_{2} \mathrm{Se}_{3}-\mathrm{MoS}_{\mathrm{x}}$ stack, photocurrent densities as high as $\sim 16 \mathrm{~mA} \mathrm{~cm}^{-2}$ were obtained at $0 \mathrm{~V}$ vs RHE in $1 \mathrm{M} \mathrm{H}_{2} \mathrm{SO}_{4}$. We also show that the decrease in photocatalytic activity is due to the $\mathrm{MoS}_{\mathrm{x}}$ catalyst, while the $\mathrm{Sb}_{2} \mathrm{Se}_{3}$ is inherently resistant to photocorrosion in the strongly acidic media. The simplicity with which these photocathodes are fabricated, combined with the high photocurrents and stability, make $\mathrm{Sb}_{2} \mathrm{Se}_{3}$ a strong candidate for scalable PEC cells.

\section{Results and discussion}

$\mathrm{Sb}_{2} \mathrm{Se}_{3}$ thin films used for this study were prepared by selenization of electrodeposited $\mathrm{Sb}$ thin films on Au-coated fluorine-doped tin oxide (FTO) substrates (the detailed procedure is provided in the methods section). The surface morphology of the $\mathrm{Sb}_{2} \mathrm{Se}_{3}$ thin films (Fig S1a) shows a grain size ranging from 300 to $600 \mathrm{~nm}$ with a largely void free surface. The X-Ray diffraction (XRD) pattern (Fig S1b) of these films was in good agreement with the orthorhombic phase of $\mathrm{Sb}_{2} \mathrm{Se}_{3}$ (JCPDS 15-0861) with no signs of secondary phases or impurities. Energy dispersive Xray spectroscopy (EDX) spectra also show the presence of Sb and Se peaks (Fig S2a), and the Raman spectrum indicates a pure $\mathrm{Sb}_{2} \mathrm{Se}_{3}$ phase (Fig S2b). ${ }^{11}$ In order to evaluate if $\mathrm{Sb}_{2} \mathrm{Se}_{3}$ could be employed as a photocathode for hydrogen evolution, the band positions of the $\mathrm{Sb}_{2} \mathrm{Se}_{3}$ were determined using Mott-Schottky (M-S) analysis. To circumvent frequency dispersion in the M-S plots, the space charge capacitance $\left(\mathrm{C}_{\mathrm{SC}}\right)$ was determined by electrochemical impedance spectroscopy (EIS). As the rich redox chemistry of Sb and Se in water in the potential range between 0 and $500 \mathrm{mV}$ vs standard hydrogen electrode (SHE) hinders the determination of $\mathrm{C}_{\mathrm{SC}}$, 
the measurement of $C_{S C}$ was performed in dry acetonitrile. The plot of $1 / C^{2}$ of the space charge capacitance reveals a p-type character of the $\mathrm{Sb}_{2} \mathrm{Se}_{3}$ and yields a flat band potential of $273 \mathrm{mV}$ vs SHE for two separate samples, with a moderate doping density of $\sim 1 \mathrm{e}^{18} \mathrm{~cm}^{3}$ (Fig S3a). X-ray photoelectron spectroscopy (XPS) measurements show an energetic distance of the fermi level $E_{\mathrm{F}}$ to the valence band maximum of $E_{\mathrm{VBM}} \sim 500 \mathrm{mV}$ (Fig S4), which is in good agreement with previously reported values for phase pure $\mathrm{Sb}_{2} \mathrm{Se}_{3}$, and suggests a moderate p-type doping of the film. ${ }^{12}$ With this information the conduction and valence band positions of $\mathrm{Sb}_{2} \mathrm{Se}_{3}$ in the $\mathrm{SHE}$ and vacuum scale were determined (Fig S3b). The conduction band of $\mathrm{Sb}_{2} \mathrm{Se}_{3}$ lies more negative than the water reduction potential and hence can be employed as a photocathode for hydrogen evolution.

Fig 1a illustrates the device architecture for the $\mathrm{Sb}_{2} \mathrm{Se}_{3}$ photocathode employing a photoelectrodeposited amorphous $\mathrm{MoS}_{\mathrm{x}}$ catalyst for the hydrogen evolution reaction. The bare $\mathrm{Sb}_{2} \mathrm{Se}_{3}$ does not show any appreciable photocurrent during light chopping (Fig $1 \mathrm{~b}$ ). However, the $\mathrm{Sb}_{2} \mathrm{Se}_{3}$ photocathode with $\mathrm{MoS}_{\mathrm{x}}$ catalyst shows a high photocurrent density $\left(\sim 5.2 \mathrm{~mA} \mathrm{~cm}{ }^{-2}\right.$ at 0 $\mathrm{V}$ vs RHE) (Fig 1b). A $\mathrm{Sb}_{2} \mathrm{Se}_{3}$-Pt photocathode was also fabricated as a bench mark system, which exhibited an earlier onset potential than the $\mathrm{Sb}_{2} \mathrm{Se}_{3}-\mathrm{MoS}_{\mathrm{x}}$ due to better catalytic activity of Pt over amorphous $\operatorname{MoS}_{\mathrm{x}}$ (Fig S5). ${ }^{13}$ It is important to note that the amorphous $\mathrm{MoS}_{\mathrm{x}}$ requires an activation to be in its catalytically active form (Fig S6). ${ }^{14}$ Large bubbles were generated from the $\mathrm{Sb}_{2} \mathrm{Se}_{3}-\mathrm{MoS}_{\mathrm{x}}$ photocathode upon illumination, and gas chromatography confirmed hydrogen evolution with $\sim 100 \%$ faradaic efficiency (Fig S7).

A recent theoretical study suggests that the ionization potential of $\mathrm{Sb}_{2} \mathrm{~S}_{3}$ is higher than the selenide, which could lead to a valence band offset at the $\mathrm{Sb}_{2} \mathrm{~S}_{3} / \mathrm{Sb}_{2} \mathrm{Se}_{3}$ interface. ${ }^{15}$ This offset can act as a hole-blocking layer, resulting in reduced interface recombination. Hence, a 
sulfurization of the $\mathrm{Sb}_{2} \mathrm{Se}_{3}-\mathrm{MoS}_{\mathrm{x}}$ stack was performed at $250{ }^{\circ} \mathrm{C}$ in order to slightly sulfurize the surface (denoted as $\mathrm{Sb}_{2} \mathrm{Se}_{3}-\mathrm{MoS}_{\mathrm{x}}-\mathrm{S}$ ). The current density vs potential plots for $\mathrm{Sb}_{2} \mathrm{Se}_{3}-\mathrm{MoS}_{\mathrm{x}}-\mathrm{S}$ show a significant improvement in the photocurrent onset $(\sim 100 \mathrm{mV})$ and typical photocurrents of $\sim 14 \mathrm{~mA} \mathrm{~cm}^{-2}$ were obtained at $0 \mathrm{~V}$ vs RHE with very low dark currents (Fig 1b, S8). Fig S9 shows the device statistics for four different $\mathrm{Sb}_{2} \mathrm{Se}_{3}-\mathrm{MoS}_{\mathrm{x}}-\mathrm{S}$ photocathodes, which consistently show photocurrent densities higher than $13 \mathrm{~mA} \mathrm{~cm}^{-2}$ at $0 \mathrm{~V}$ vs RHE, and higher than $20 \mathrm{~mA} \mathrm{~cm}^{-2}$ at $-0.16 \mathrm{~V}$ vs RHE. A thermal annealing control experiment in the absence of sulfur confirmed that sulfur was required for the improvement in performance (Fig S9). The incident photon to current efficiency (IPCE) spectrum of the $\mathrm{Sb}_{2} \mathrm{Se}_{3}-\mathrm{MoS}_{\mathrm{x}}-\mathrm{S}$ sample revealed a similar onset as the non-sulfurized sample, indicating that the bandgap was unaffected by the sulfurization treatment (Fig 1c). The IPCE onset of $\sim 1060 \mathrm{~nm}$ coincides with the bandgap of $\mathrm{Sb}_{2} \mathrm{Se}_{3}$, indicating that all above bandgap radiation is able to be converted in these photocathodes, with greater than $40 \%$ IPCE across the visible spectrum $(400-700 \mathrm{~nm})$ for the sulfurized sample. STEM-EDX elemental mapping revealed that the $\mathrm{Mo} / \mathrm{S}$ was localized close to the surface without any sulfur penetration into the $\mathrm{Sb}_{2} \mathrm{Se}_{3}$ layer (Fig 2a).

To elucidate the reason for improvement in the PEC performance, the chemical composition was further investigated by XPS. Figure $2 \mathrm{~b}$ and $\mathrm{c}$ shows the $\mathrm{Sb} 3 \mathrm{~d}$ XPS spectra of $\mathrm{Sb}_{2} \mathrm{Se}_{3}-\mathrm{MoS}_{\mathrm{x}}$ before and after sulfurization. The key feature of these spectra is that the peaks corresponding to $\mathrm{Sb}_{2} \mathrm{O}_{3}$ decreased upon sulfurization treatment. This partial removal of $\mathrm{Sb}_{2} \mathrm{O}_{3}$ after the sulfurization could result in the improvement of the onset potential due to reduced interface recombination (e.g. due to trap elimination or better charge separation) and decreased contact resistance. ${ }^{16}$ Upon sulfurization, a conversion of $\mathrm{Sb}_{2} \mathrm{O}_{3}$ to $\mathrm{Sb}_{2} \mathrm{~S}_{3}$ is likely, but the effects are difficult to quantify by XPS due to the similarities in core level emission between $\mathrm{Sb}_{2} \mathrm{~S}_{3}$ and 
$\mathrm{Sb}_{3} \mathrm{Se}_{3}$, making the two components almost indistinguishable in the Sb3d spectra. Thus, further analysis was carried out in order to verify this hypothesis. There was not any significant change in the surface morphology (Fig S11a and b) after sulfurization of the $\mathrm{Sb}_{2} \mathrm{Se}_{3}-\mathrm{MoS}_{\mathrm{x}}$. Additionally, the XRD patterns and Raman spectrum were nearly identical for the sulfurized and nonsulfurized samples (Fig S11c and d). The $\mathrm{Sb}_{2} \mathrm{Se}_{3}-\mathrm{MoS}_{\mathrm{x}}-\mathrm{S}$ also did not show any Raman peaks corresponding to crystalline $\mathrm{MoS}_{2}$, indicating that the crystallinity of the $\mathrm{MoS}_{\mathrm{x}}$ catalyst did not change with sulfurization treatment. ${ }^{17}$ A prolonged sulfurization $(2 \mathrm{~h})$ produced a new Raman peak attributed to $\mathrm{Sb}_{2} \mathrm{~S}_{3}$ (Fig $\mathrm{S} 12 \mathrm{a}$ ), which did not significantly affect the current densitypotential characteristics in comparison to the shorter sulfurization time (Fig S12b). These data support our hypothesis of sulfurization of the $\mathrm{Sb}_{2} \mathrm{O}_{3}$ at the surface for the improvement of the photoelectrochemical performance.

Figure 3a shows the photocurrent stability of $\mathrm{Sb}_{2} \mathrm{Se}_{3}-\mathrm{MoS}_{\mathrm{x}}-\mathrm{S}$ in $1 \mathrm{M} \mathrm{H}_{2} \mathrm{SO}_{4}$ at $0 \mathrm{~V}$ vs $\mathrm{RHE}$, where the photocurrent density starts at $\sim 14 \mathrm{~mA} \mathrm{~cm}^{-2}$ upon illumination and slowly decreased to $\sim 9.8 \mathrm{~mA} \mathrm{~cm}^{-2}$ over a period of $2 \mathrm{~h}$. Most of the photoactivity was recovered upon reapplication of the $\mathrm{MoS}_{\mathrm{x}}$ catalyst, although the photocurrent again decreased gradually from $\sim 13 \mathrm{~mA} \mathrm{~cm}^{-2}$ to $\sim 10 \mathrm{~mA} \mathrm{~cm}{ }^{-2}$ over another $2 \mathrm{~h}$. Since the photocurrent was recovered after the reapplication of the catalyst, this would indicate loss of the $\mathrm{MoS}_{\mathrm{x}}$ catalyst from the surface during operation. ${ }^{14}$ In order to verify this, XPS sputter depth profiles of the $\mathrm{Sb}_{2} \mathrm{Se}_{3}-\mathrm{MoS}_{\mathrm{x}}-\mathrm{S}$ before and after operation were obtained. Despite the measurement uncertainties potentially introduced by preferential sputtering, qualitative comparisons between similar samples are possible. In this case the sample after operation shows a much faster decay of the relative atomic concentrations for Mo and $\mathrm{S}$ with increasing sputter depth as compared with the sample before operation (Fig 3b), indicating a loss of $\mathrm{MoS}_{\mathrm{x}}$ catalyst from the surface during operation. Notably, an increase of oxygen is also 
observed after measurement that is attributed to slight oxidation of the $\mathrm{MoS}_{\mathrm{x}}$ layer, as an increase in $\mathrm{Sb}_{2} \mathrm{O}_{3}$ was not observed by XPS (Fig S13).

In order to further improve the stability of the $\mathrm{Sb}_{2} \mathrm{Se}_{3}-\mathrm{MoS}_{\mathrm{x}}$ photocathode, a thicker $\mathrm{MoS}_{\mathrm{x}}$ catalyst was loaded onto the $\mathrm{Sb}_{2} \mathrm{Se}_{3}$ photocathode [30 nm]. The thicker catalyst resulted in a significant improvement of the photocurrent stability in a $1 \mathrm{~h}$ time frame for both the sulfurized and non-sulfurized samples (Fig S14), and a stability up to $20 \mathrm{~h}$ was observed for the nonsulfurized sample (Fig 4a). For the higher performing sulfurized sample, high photocurrents were observed for hours, but the performance decayed to $1 \mathrm{~mA} \mathrm{~cm}{ }^{-2}$ after $10 \mathrm{~h}$ and then to nearly 0 $\mathrm{mA} \mathrm{cm}{ }^{-2}$ after $20 \mathrm{~h}$. In order to decouple whether the degradation at high current densities $(>14$ $\mathrm{mA} \mathrm{cm}{ }^{-2}$ ) was due to catalyst or the $\mathrm{Sb}_{2} \mathrm{Se}_{3}$, a $\mathrm{MoS}_{\mathrm{x}}$ layer was deposited on a glassy carbon electrode using the same conditions as on the $\mathrm{Sb}_{2} \mathrm{Se}_{3}$ thin film. A potential corresponding to an initial current density of $14 \mathrm{~mA} \mathrm{~cm}^{-2}$ was applied to the $\mathrm{MoS}_{\mathrm{x}}$ electrode on glassy carbon in $1 \mathrm{M}$ $\mathrm{H}_{2} \mathrm{SO}_{4}$ under 1 sun illumination, and the current density was monitored over time (Figure S15). The trend is similar to the photocathode experiment with the electrode completely degrading to 0 $\mathrm{mA} \mathrm{cm}{ }^{-2}$ after $4 \mathrm{~h}$. Fig $4 \mathrm{~b}$ shows that at the surface of $\mathrm{Sb}_{2} \mathrm{Se}_{3}-\mathrm{MoS}_{\mathrm{x}}$ after $20 \mathrm{~h}$ operation the relative oxygen content is significantly increased, while the relative sulfur content is significantly decreased. This observation indicates a conversion of $\mathrm{MoS}_{\mathrm{x}}$ to $\mathrm{MoO}_{\mathrm{x}}$, which would deteriorate the catalytic performance for the HER reaction. This effect could be further accelerated when operating at higher current densities $\left(>14 \mathrm{~mA} \mathrm{~cm}^{-2}\right)$, hence resulting in faster degradation of the $\mathrm{MoS}_{\mathrm{x}}$ catalyst in the high performing case. It has been shown that corrosion of $\mathrm{MoS}_{2}$ can be induced by conversion of the $\mathrm{MoS}_{2}$ into $\mathrm{MoO}_{\mathrm{x}}$, particularly at the edge sites. ${ }^{18}$ Since the edge sites are the main catalytically active sites in $\mathrm{MoS}_{\mathrm{x}}$, corrosion of these sites would result in the loss of catalytic activity. 
To further evaluate the intrinsic stability of $\mathrm{Sb}_{2} \mathrm{Se}_{3}$ thin film, a photocorrosion stress test was carried out. Cyclic voltammetry of the bare $\mathrm{Sb}_{2} \mathrm{Se}_{3}$ thin film was performed in $1 \mathrm{M} \mathrm{H}_{2} \mathrm{SO}_{4}$ under 1 sun illumination for 285 cycles $(10 \mathrm{mV} / \mathrm{s}, 4.75 \mathrm{~h}$, Fig $5 \mathrm{a})$. The bare $\mathrm{Sb}_{2} \mathrm{Se}_{3}$ thin film does not show significant photo corrosion currents during the CV cycling. After 285 cycles, $\mathrm{MoS}_{\mathrm{x}}$ catalyst $(\sim 30 \mathrm{~nm})$ was coated onto the $\mathrm{Sb}_{2} \mathrm{Se}_{3}$ thin film, and it exhibited similar PEC performance to a freshly prepared $\mathrm{Sb}_{2} \mathrm{Se}_{3}-\mathrm{MoS}_{\mathrm{x}}$ photocathode, with fairly good photocurrent stability for $10 \mathrm{~h}$ (Fig $5 \mathrm{~b}$ and $\mathrm{S} 16)$. The $\mathrm{Sb}_{2} \mathrm{Se}_{3}$ photocathode is therefore remarkably robust under the harsh conditions of the strongly acidic electrolyte and full sun irradiation. $\mathrm{Sb}_{2} \mathrm{Se}_{3}$ is therefore a strong candidate for practical PEC water splitting cells due to its intrinsic stability in strong acid, as well as high efficiency as a photoabsorber when produced with scalable and low-cost methods.

\section{Conclusion}

We demonstrated highly efficient $\mathrm{Sb}_{2} \mathrm{Se}_{3}$ photocathodes using Earth-abundant $\mathrm{MoS}_{\mathrm{x}}$ as a catalyst for the first time. By employing a post-sulfurization strategy, photocurrent densities as high as $16 \mathrm{~mA} \mathrm{~cm}^{-2}$ were obtained. The post-sulfurization does not convert the $\mathrm{Sb}_{2} \mathrm{Se}_{3}$ film to $\mathrm{Sb}_{2} \mathrm{~S}_{3}$ or $\mathrm{Sb}_{2}(\mathrm{~S}, \mathrm{Se})_{3}$, but rather partially converts the $\mathrm{Sb}_{2} \mathrm{O}_{3}$ on the surface to $\mathrm{Sb}_{2} \mathrm{~S}_{3}$ forming an effective hole blocking contact leading to an earlier photocurrent onset. The $\mathrm{Sb}_{2} \mathrm{Se}_{3}$ photocathodes also exhibited good photocurrent stability in strong acid $\left(1 \mathrm{M} \mathrm{H}_{2} \mathrm{SO}_{4}\right)$ for $20 \mathrm{~h}$ without any protection layers. We also showed that the $\mathrm{Sb}_{2} \mathrm{Se}_{3}$ thin film is robustly stable towards photocorrosion in strong acid, in contrast to other high efficiency photocathodes. The primary loss in the catalytic activity of the photocathodes at high current densities was due to changes in the $\mathrm{MoS}_{\mathrm{x}}$ rather than degradation of the $\mathrm{Sb}_{2} \mathrm{Se}_{3}$ absorber. 


\section{Experimental section}

Synthesis of $\boldsymbol{S b}_{2} \mathrm{Se}_{3}$ thin films: FTO substrates used were FTO TEC 15 from Pilkington. $150 \mathrm{~nm}$ of Au was coated onto the FTO substrates using a Safematic CCU-010 sputter coater. Sb metal was electrodeposited onto the Au-coated FTO substrates following a literature procedure in a three-electrode configuration from a solution containing $15 \mathrm{mM} \mathrm{K}_{2}\left(\mathrm{Sb}_{2}\left(\mathrm{C}_{4} \mathrm{H}_{2} \mathrm{O}_{6}\right)_{2}\right.$ and $50 \mathrm{mM}$ tartaric acid at a $\mathrm{pH}$ of 1.3 (pH adjusted using conc. sulfuric acid, 95\%) and a potential of $-0.3 \mathrm{~V}$ vs $\mathrm{Ag} / \mathrm{AgCl}{ }^{19}$ The thickness of the $\mathrm{Sb}$ metal was controlled by limiting the charge passed to 1.4 $\mathrm{C} \mathrm{cm}^{-2}$. The electrodeposited $\mathrm{Sb}$ metal was selenized in a one-zone furnace using selenium pellets $(30 \mathrm{mg})$ as the selenium source in an Ar atmosphere at $350{ }^{\circ} \mathrm{C}$. A ramping rate of $15{ }^{\circ} \mathrm{C}$ $\min ^{-1}$ was used to reach $350{ }^{\circ} \mathrm{C}$ and the sample was maintained at this temperature for $40 \mathrm{~min}$. Once the process was finished, the furnace was opened to cool down to room temperature within 60 min. Sulfurization of $\mathrm{Sb}_{2} \mathrm{Se}_{3}$ thin films was carried out in a two-zone furnace. Elemental sulfur powder (300 mg) was used as sulfur source to maintain a sulfur atmosphere in the tube for the entire sulfurization process. The $\mathrm{Sb}_{2} \mathrm{Se}_{3}$ was kept at $250{ }^{\circ} \mathrm{C}$ and the sulfur source was kept at $200{ }^{\circ} \mathrm{C}$. The ramping rate to reach the required temperatures was $15^{\circ} \mathrm{C} \min ^{-1}$ and these temperatures were maintained for a period of $40 \mathrm{~min}$. Once the process was finished the furnace was opened to cool to room temperature within $60 \mathrm{~min}$.

Photoelectrodeposition of $M o S_{x}$ and Pt catalyst: $\mathrm{MoS}_{\mathrm{x}}$ photoelectrodeposition was carried out using a $5 \mathrm{mM}\left(\mathrm{NH}_{4}\right)_{2}\left[\mathrm{MoS}_{4}\right]$ solution containing $0.5 \mathrm{M} \mathrm{Na}_{2} \mathrm{SO}_{4}$ in a 2-electrode setup under 1 sun illumination using a procedure described in the literature. ${ }^{20} \mathrm{~A}$ constant current of $-50 \mu \mathrm{A} \mathrm{cm}-$

${ }^{2}$ was passed for 10 minutes for the thin $\operatorname{MoS}_{\mathrm{x}}(\sim 15 \mathrm{~nm})$. The thickness was estimated from the elemental mapping using STEM (Fig 2a). For thicker $\operatorname{MoS}_{\mathrm{x}}(\sim 30 \mathrm{~nm})$, a constant current of -120 $\mu \mathrm{A} \mathrm{cm}{ }^{-2}$ was passed for $10 \mathrm{~min}$. The thickness for the thicker $\mathrm{MoS}_{\mathrm{x}}$ layer was estimated by 
comparing the XPS sputter depth profiles. After the $\mathrm{MoS}_{\mathrm{x}}$ deposition, the electrode was thoroughly washed with distilled water. Platinum catalyst was photoelectrodeposited from an aqueous solution of $1 \mathrm{mM} \mathrm{H}_{2} \mathrm{PtCl}_{6}$ containing $0.1 \mathrm{M} \mathrm{Na}_{2} \mathrm{SO}_{4}$, using a constant current of -0.03 $\mathrm{mA} \mathrm{cm}{ }^{-2}$ for 10 min with constant irradiation from simulated 1 sun illumination.

Morphology and crystal structure characterization of $\mathrm{Sb}_{2} \mathrm{Se}_{3}$ thin films: The plan view and cross sectional scanning electron microscopy (SEM) images of $\mathrm{Sb}_{2} \mathrm{Se}_{3}$ thin films were obtained using a SEM - Zeiss Supra 50 VP that was equipped with an energy dispersive X-ray spectroscopy (EDX) detector (genesis). X-ray diffraction (Rigaku smartlab diffractometer) and Raman spectrum were obtained using a Renishaw System 2000 (excitation wavelength $532 \mathrm{~nm}$ and laser spot size $\sim 2 \mu \mathrm{m})$.

\section{Electrochemical and photoelectrochemical characterization of $\mathrm{Sb}_{2} \mathrm{Se}_{3} \mathrm{PEC}$ :}

The photoelectrochemical measurement of the photocathodes was evaluated in a three-electrode configuration using a BioLogic SP-200 potentiostat under irradiation from simulated AM 1.5 G illumination, calibrated using a silicon diode from PV Measurements, Inc. (100 mW cm $\left.{ }^{-2}\right)$. A 1 $\mathrm{M} \mathrm{H}_{2} \mathrm{SO}_{4}$ ( $\mathrm{pH} 0$ ) solution was used as the electrolyte. The reference electrode was $\mathrm{Hg} / \mathrm{HgSO}_{4}$ (sat'd $\mathrm{KCl}$ ), and a Pt wire was used as the counter electrode. Before measurement, the electrolyte was sparged with $\mathrm{N}_{2}$ for at least 30 min to remove dissolved oxygen. The photocathode area was defined using epoxy (Loctite 9461) and the active area was determined by counting pixels using the image processing software gimp. The conversion between potentials vs. $\mathrm{Hg} / \mathrm{HgSO}_{4}$ and vs. RHE was performed using the equation:

$\mathrm{E}($ vs. $\mathrm{RHE})=\mathrm{E}\left(\right.$ vs. $\left.\mathrm{Hg} / \mathrm{HgSO}_{4}\right)+0.059 \mathrm{~V} \times \mathrm{pH}+0.634 \mathrm{~V}\left(\mathrm{E}_{\mathrm{Hg} / \mathrm{HgSO} 4}\right)$

Incident photon-to-current efficiency (IPCE) was measured on a home-built IPCE system featuring a halogen light source with double monochromator and white light bias. The IPCE was 
measured in a three-electrode configuration using $\mathrm{Hg} / \mathrm{HgSO}_{4}$ (sat'd $\mathrm{KCl}$ ) reference electrode and Pt wire as the counter electrode at $0 \mathrm{~V}$ versus RHE at $5 \mathrm{~nm}$ wavelength intervals. The Faradaic efficiency was measured in a glass three-compartment cell using a Pt wire as counter electrode, $\mathrm{Ag} / \mathrm{AgCl}$ reference electrode and $1 \mathrm{M} \mathrm{H}_{2} \mathrm{SO}_{4}(\mathrm{pH}$ 0) electrolyte. The solution was stirred and sparged with Argon as carrier gas at a flow rate of $20 \mathrm{ml} \mathrm{min}^{-1}$. The composition of the carrier gas was analyzed in a 450-GC Gas Chromatograph (Bruker Daltonics GmbH) every two minutes. For faradaic efficiency measurement $0 \mathrm{~V}$ vs RHE was applied for one hour under illumination by a white light LED. The light intensity was chosen to match the current density under one sun illumination in PEC measurements. The amount of hydrogen detected by the GC was determined by creating a calibration curve using several different galvanostatic current values applied to a freshly cleaned Pt working electrode in two electrode mode, and assuming $100 \%$ faradaic efficiency for the HER on Pt.

\section{Mott Schottky analysis and electrochemical impedance spectroscopy}

The doping and the flat band potential were determined by electrochemical impedance analysis. Due to the rich chemistry of $\mathrm{Sb}$ and $\mathrm{Se}$ in water in the required potential region for MottSchottky (M-S) analysis, which complicates the interpretation, the M-S analysis was performed in dry acetonitrile solution with $0.2 \mathrm{M}$ tetrabutylammoniumhexafluorophosphate as conduction salt. A leak free reference electrode (EDAQ; ET072) was used and calibrated against ferrocene in acetonitrile. The conversion of the electrochemical electrode potential to the absolute electrode potential was according to the IUPAC standard of $\mathrm{E}_{(\mathrm{abs})}=\mathrm{E}_{(\mathrm{SHE})}+4.4 \mathrm{~V}^{21}$ The impedance measurement was performed by applying a $15 \mathrm{mV}$ sinusoidal potential perturbation onto the stepped bias potential $(25 \mathrm{mV}$ steps from -0.4 to $0.6 \mathrm{vs} \mathrm{SHE})$. The frequency range for the potential perturbation was $200 \mathrm{kHz}$ down to $0.2 \mathrm{~Hz}$. $16 \mathrm{~s}$ was used as stabilization time at 
each bias potential step. The Nyquist plots at the different bias potentials showed one semicircle and were therefore fitted with a simplified Randles circuit consisting of the series resistance (from cables, contacts and electrolyte), the charge transfer resistance $\left(\mathrm{R}_{\mathrm{ct}}\right)$ and the space charge capacitance $\left(\mathrm{C}_{\mathrm{SC}}\right)$. To account for the roughness of the semiconductor surface, a constant phase element (CPE) was used to model the space charge capacitance (with the exponent of the CPE not going below 0.85 during the fitting procedure).

After the fitting of the Nyquist plots, the CPE values were converted into the space charge

$$
\mathrm{C}_{S C}=\frac{\left(R_{c t} \times Q\right)^{\left(\frac{1}{n}\right)}}{R_{c t}}
$$

capacitance:

with $\mathrm{R}_{\mathrm{ct}}$ as the charge transfer resistance, $\mathrm{Q}$ as the charge from the CPE and $\mathrm{n}$ as the exponent of the CPE. By the fitting of the Nyquist plots the absolute values of the space charge capacitance are determined and therefore no frequency dispersion appears in the M-S analysis.

The space charge capacitance was used for the M-S analysis, relating $1 / \mathrm{C}_{\mathrm{sc}}{ }^{2}$ vs the applied potential to the flat band potential ( $\propto \mathrm{x}$ axis intercept) and doping ( $\propto$ slope):

$$
\frac{1}{C_{S C}^{2}}=\frac{2}{N_{A} \varepsilon \varepsilon_{0} q}\left(E-E_{F B}-\frac{k T}{q}\right)
$$

where $\mathrm{q}$ is the charge of an electron, $\varepsilon$ is the relative dielectric constant of the materials $(\varepsilon=$ $15),{ }^{22} \varepsilon_{0}$ is the permittivity of free space, $\mathrm{N}_{\mathrm{A}}$ acceptor density (for a p-type semiconductor), $\mathrm{E}$ is the potential applied, $\mathrm{E}_{\mathrm{FB}}$ is the flat band potential, $\mathrm{k}$ is the Boltzmann constant and $\mathrm{T}$ is the temperature. As the surface of the absorber is not flat a roughness factor of 1.5 was assumed.

\section{XPS}

X-ray photoelectron spectroscopy (XPS) was conducted using a Physical Electronics (PHI) Quantum 2000 X-ray photoelectron spectrometer featuring monochromatic Al-K $\alpha$ radiation, 
generated from an electron beam operated at $15 \mathrm{kV}$ and $32.3 \mathrm{~W}$. The energy scale of the instrument was calibrated using $\mathrm{Au}$ and $\mathrm{Cu}$ reference samples. The analysis was conducted at $1 \times 10^{-6} \mathrm{~Pa}$, with an electron take off angle of $45^{\circ}$ and a pass energy of $23.50 \mathrm{eV}$. The measurements were performed without neutralizer. If not stated otherwise, the sputter depth profiles were obtained using $\mathrm{Ar}$ ions $(1 \mathrm{kV}$ potential) on an area of approximately $2 \times 2 \mathrm{~mm}$. Surface elemental concentrations were determined from the photoelectron spectra after Shirley background subtraction using the instrument specific sensitivity factors for calculation. As necessary, the core level spectra were fitted to deconvolute spectra with contributions from multiple elements. In particular fits of the Sb3d core level spectra were carried out for a semiquantitative comparison of the different samples. A symmetric shape (GL 30) was assumed for the core level emissions with a separation of $\Delta E=9.34 \mathrm{eV}$ for the $\mathrm{Sb} 3 \mathrm{~d}$ doublet.

\section{TEM and FIB sample preparation}

A TEM lamella was prepared by the in-situ lift-out technique on a Zeiss NVision 40 FIB-SEM. The lamella was thinned using $30 \mathrm{kV} \mathrm{Ga}+$ ions. For the $5-\mathrm{kV}$ showering, to reduce the thickness and limit the damage of the layer, the lamella was tilted $10^{\circ}$ into the beam. The FEI Talos F200X transmission electron microscope was operated at $200 \mathrm{kV}$ and was equipped with a X-FEG emitter. The microscope can be operated in TEM as well as in STEM mode, and provides a point-to-point resolution of $0.12 \mathrm{~nm}$ for TEM and $0.16 \mathrm{~nm}$ for STEM imaging. For elemental analysis, it is equipped with a Super-X EDS (windowless, 4-detector configuration).

\section{References}

$1 \quad$ S. Styring, Faraday Discuss., 2012, 155, 357-376.

2 M. G. Walter, E. L. Warren, J. R. McKone, S. W. Boettcher, Q. Mi, E. A. Santori and N. 
S. Lewis, Chem. Rev., 2010, 110, 6446-6473.

3 R. Sathre, J. B. Greenblatt, K. Walczak, I. D. Sharp, J. C. Stevens, J. W. Ager and F. A. Houle, Energy Environ. Sci., 2016, 9, 803-819.

4 D. M. Powell, M. T. Winkler, H. J. Choi, C. B. Simmons, D. B. Needleman and T. Buonassisi, Energy Environ. Sci., 2012, 5, 5874-5883.

5 M. Luo, M. Leng, X. Liu, J. Chen, C. Chen, S. Qin and J. Tang, Appl. Phys. Lett., 2014, 104, 173904.

6 L. Wang, D.-B. Li, K. Li, C. Chen, H.-X. Deng, L. Gao, Y. Zhao, F. Jiang, L. Li, F. Huang, Y. He, H. Song, G. Niu and J. Tang, Nat. Energy, 2017, 2, 17046.

7 J. Kim, W. Yang, Y. Oh, H. Lee, S. Lee, H. Shin, J. Kim and J. Moon, J. Mater. Chem. A, $2017,5,2180-2187$.

8 C. G. Morales-Guio, L. Liardet, M. T. Mayer, S. D. Tilley, M. Grätzel and X. Hu, Angew. Chemie Int. Ed., 2015, 54, 664-667.

9 J. Gu, J. A. Aguiar, S. Ferrere, K. X. Steirer, Y. Yan, C. Xiao, J. L. Young, M. Al-Jassim, N. R. Neale and J. A. Turner, Nat. Energy, 2017, 2, 16192.

10 C. G. Morales-Guio, S. D. Tilley, H. Vrubel, M. Grätzel and X. Hu, Nat. Commun., 2014, 5,3059 .

11 S. L. Benjamin, C. H. de Groot, A. L. Hector, R. Huang, E. Koukharenko, W. Levason and G. Reid, J. Mater. Chem. C, 2015, 3, 423-430.

12 S. Siol, P. Schulz, M. Young, K. A. Borup, G. Teeter and A. Zakutayev, Adv. Mater. Interfaces, 2016, 3, 1600755. 
13 D. Merki, S. Fierro, H. Vrubel and X. Hu, Chem. Sci., 2011, 2, 1262-1267.

14 J. D. Benck, Z. Chen, L. Y. Kuritzky, A. J. Forman and T. F. Jaramillo, ACS Catal., 2012, 2, 1916-1923.

15 M. A. Tumelero, R. Faccio and A. A. Pasa, J. Phys. Chem. C, 2016, 120, 1390-1399.

16 C. Chen, Y. Zhao, S. Lu, K. Li, Y. Li, B. Yang, W. Chen, L. Wang, D. Li, H. Deng, F. Yi and J. Tang, Adv. Energy Mater., 2017, 1700866.

17 S. Luo, X. Qi, L. Ren, G. Hao, Y. Fan, Y. Liu, W. Han, C. Zang, J. Li and J. Zhong, J. Appl. Phys., 2014, 116, 164304.

18 E. Parzinger, B. Miller, B. Blaschke, J. A. Garrido, J. W. Ager, A. Holleitner and U. Wurstbauer, ACS Nano, 2015, 9, 11302-11309.

19 W. Septina, S. Ikeda, Y. Iga, T. Harada and M. Matsumura, Thin Solid Films, 2014, 550, $700-704$.

20 P. D. Tran, S. S. Pramana, V. S. Kale, M. Nguyen, S. Y. Chiam, S. K. Batabyal, L. H. Wong, J. Barber and J. Loo, Chem. - A Eur. J., 2012, 18, 13994-13999.

21 S. T. Tti, Pure Appl. Chem., 1986, 58, 955-966.

22 O. Madelung, U. Rössler and M. Schulz, Eds., Springer Berlin Heidelberg, Berlin, Heidelberg, 1998, pp. 1-6. 


\section{Acknowledgements}

This work was supported by the University of Zurich, the University Research Priority Program

(URPP) LightChEC, and the Swiss National Science Foundation (AP Energy Grant \# PYAPP2

160586). Sebastian Siol acknowledges funding from the COST project IZCNZ0-174856

C16.0075, in the COST Action MP1407 (e-MINDS). 


\section{Figures}

a
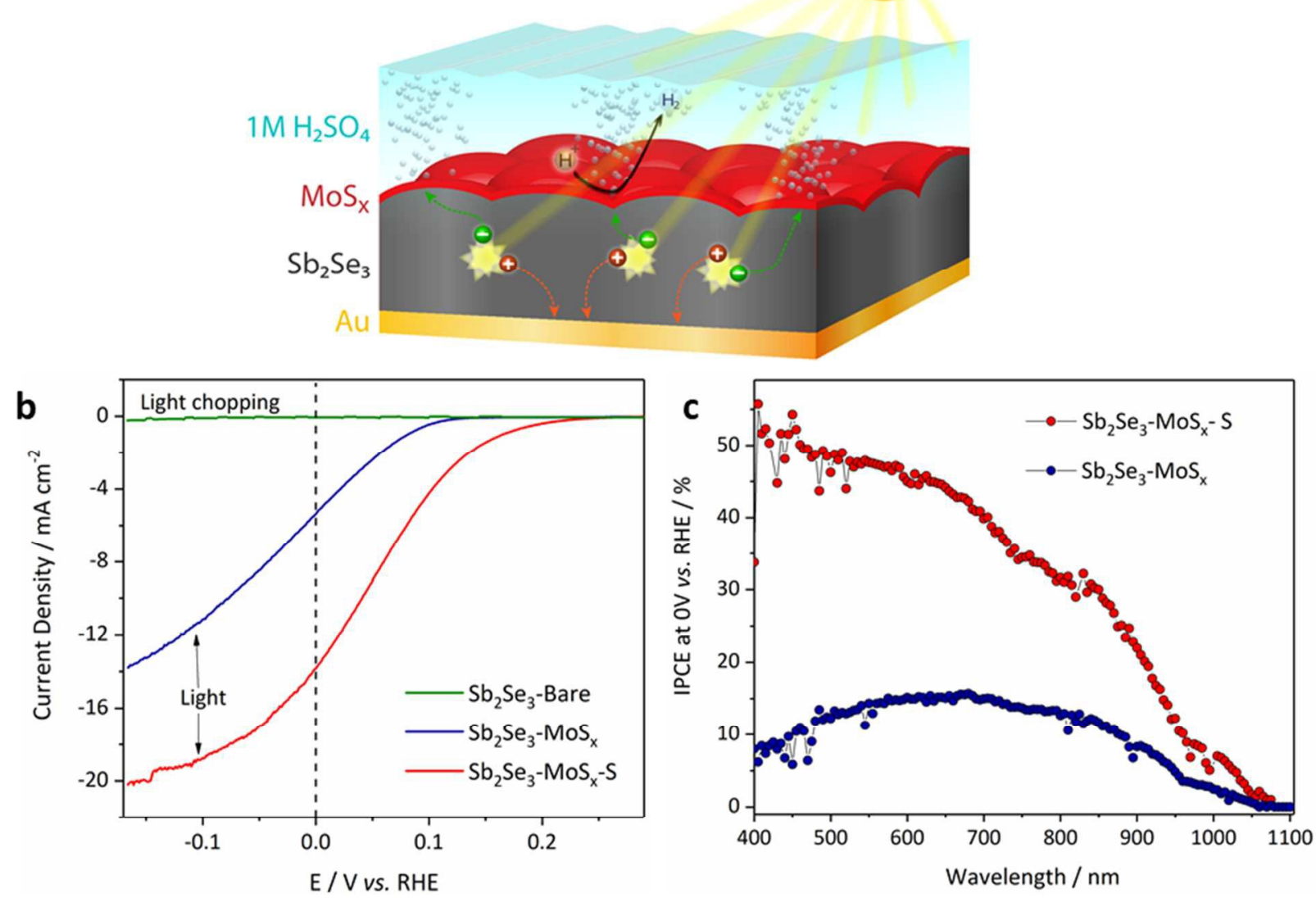

Figure 1. a Schematic representation of $\mathrm{Sb}_{2} \mathrm{Se}_{3}-\mathrm{MoS}_{\mathrm{x}}$ photocathode. b Current density-potential characteristics of bare $\mathrm{Sb}_{2} \mathrm{Se}_{3}$ (light chopping), $\mathrm{Sb}_{2} \mathrm{Se}_{3}-\mathrm{MoS}_{\mathrm{x}}$ (non-sulfurized) and $\mathrm{Sb}_{2} \mathrm{Se}_{3}-\mathrm{MoS}_{\mathrm{x}^{-}}$ $\mathrm{S}$ (sulfurized) photocathode in $1 \mathrm{M} \mathrm{H}_{2} \mathrm{SO}_{4}$ under simulated 1 sun illumination $\left(100 \mathrm{~mW} \mathrm{~cm}^{-2}\right)$. c IPCE spectra of $\mathrm{Sb}_{2} \mathrm{Se}_{3}-\mathrm{MoS}_{\mathrm{x}}$ and $\mathrm{Sb}_{2} \mathrm{Se}_{3}-\mathrm{MoS}_{\mathrm{x}}-\mathrm{S}$ photocathodes in $1 \mathrm{M} \mathrm{H}_{2} \mathrm{SO}_{4}$ at $0 \mathrm{~V}$ vs RHE. 
a

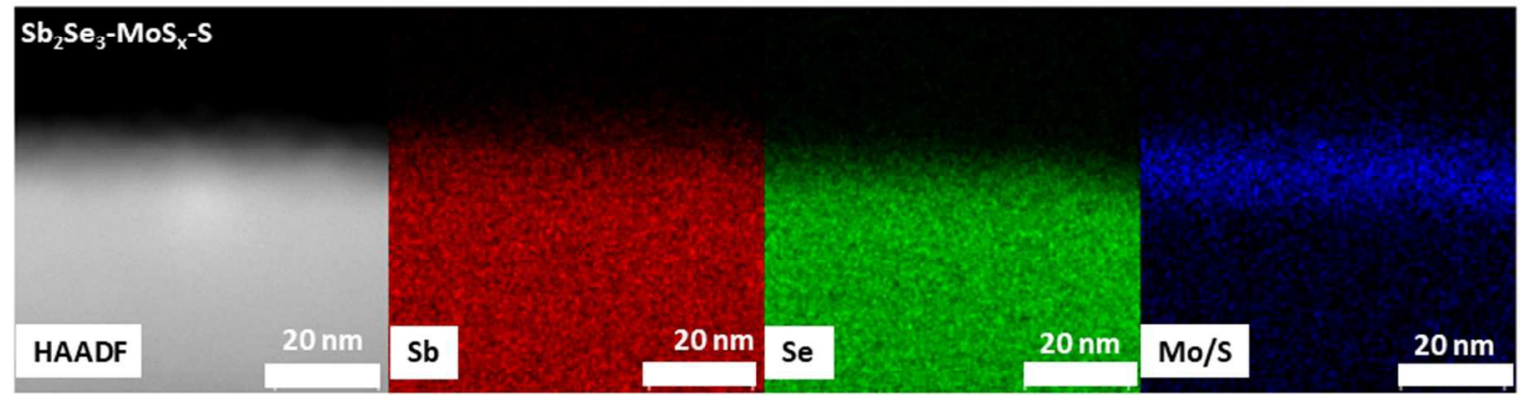

b
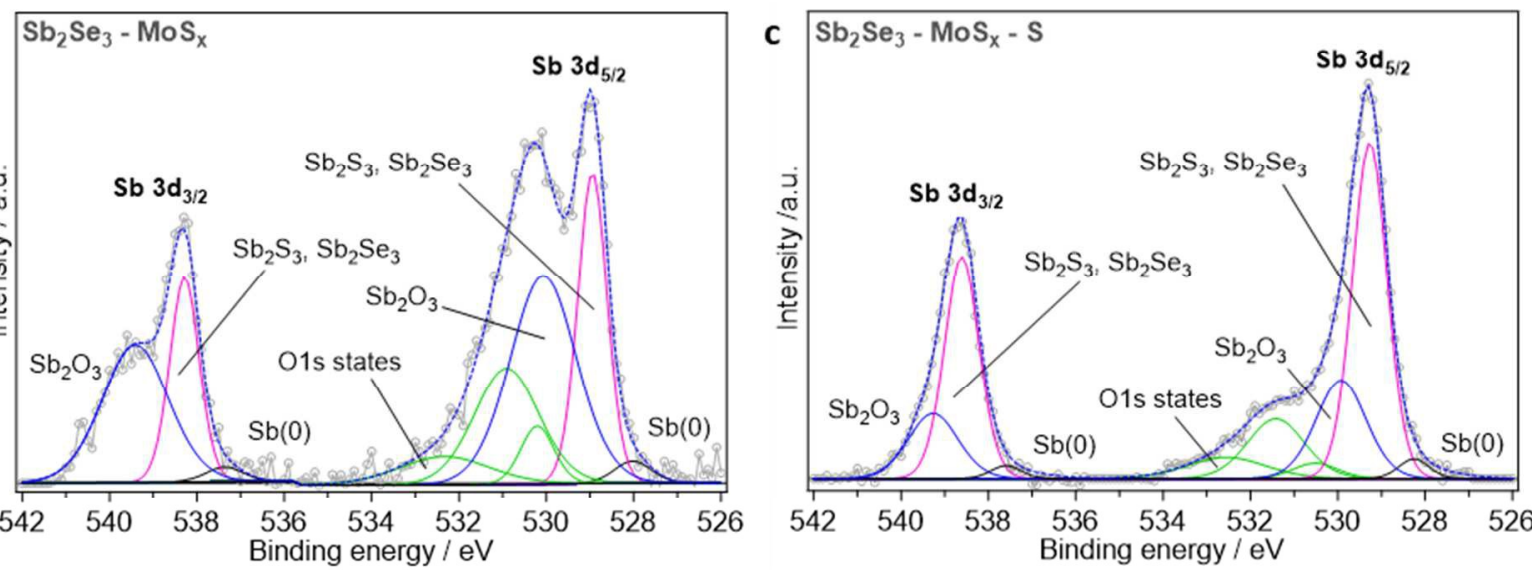

Figure 2. a STEM HAADF image and EDX elemental mapping of $\mathrm{Sb}_{2} \mathrm{Se}_{3}-\mathrm{MoS}_{\mathrm{x}}-\mathrm{S}$ (sulfurized). b XPS core level spectrum of $\mathrm{Sb} 3 \mathrm{~d}$ for $\mathrm{Sb}_{2} \mathrm{Se}_{3}-\mathrm{MoS}_{\mathrm{x}}$ (non-sulfurized). c XPS core level spectrum of $\mathrm{Sb} 3 \mathrm{~d}$ for $\mathrm{Sb}_{2} \mathrm{Se}_{3}-\mathrm{MoS}_{\mathrm{x}}-\mathrm{S}$ (sulfurized). 


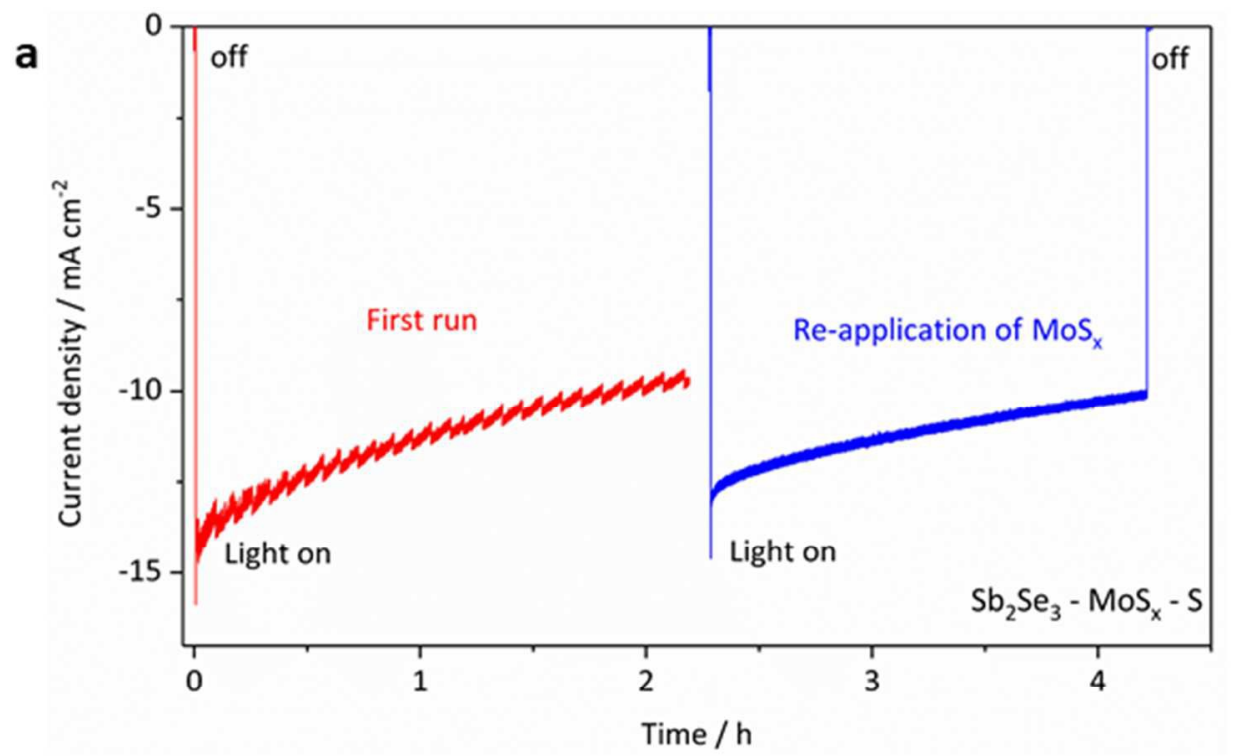

b

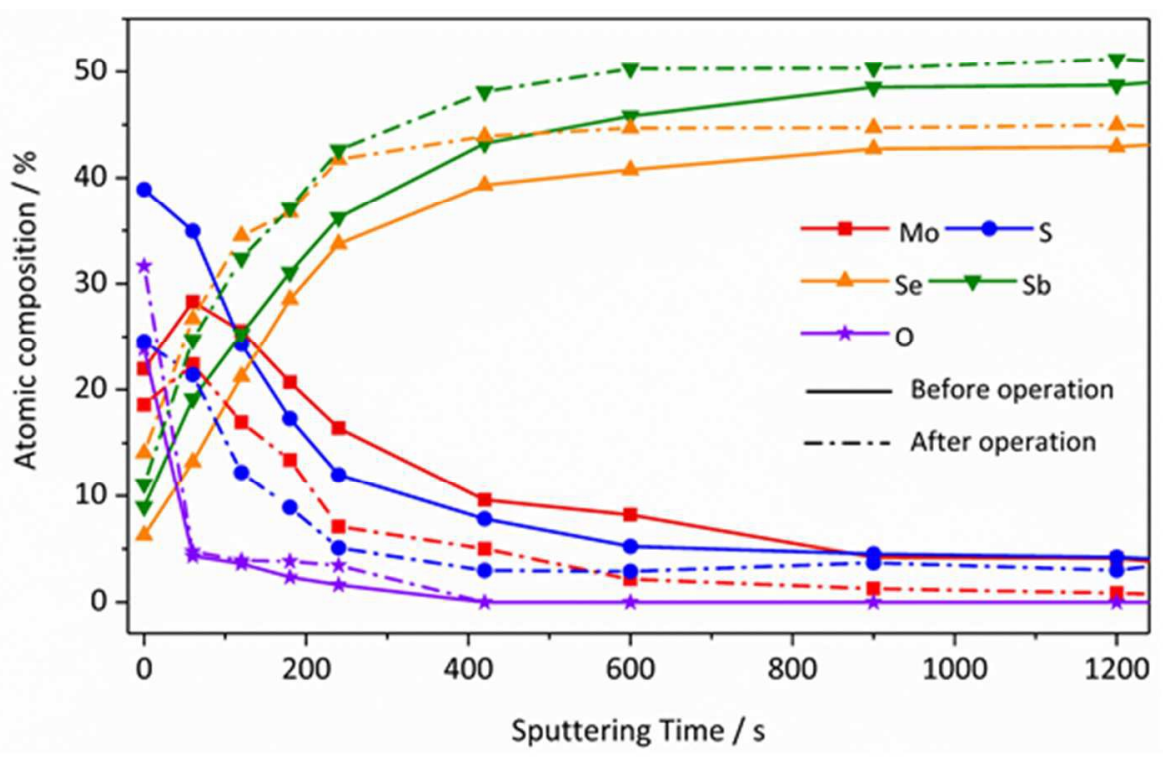

Figure 3. a Current density vs time plots for $\mathrm{Sb}_{2} \mathrm{Se}_{3}-\mathrm{MoS}_{\mathrm{x}}-\mathrm{S}(\sim 15 \mathrm{~nm} \mathrm{MoS}$ thickness $)$ in $1 \mathrm{M}$ $\mathrm{H}_{2} \mathrm{SO}_{4}$ at $0 \mathrm{~V}$ vs RHE at 1 sun illumination $\left(100 \mathrm{~mW} \mathrm{~cm}{ }^{-2}\right)$. b XPS depth profile of $\mathrm{Sb}_{2} \mathrm{Se}_{3^{-}}$ $\mathrm{MoS}_{\mathrm{x}}-\mathrm{S}$ before (as deposited) and after $2 \mathrm{~h}$ stability measurement ( $\sim 15 \mathrm{~nm} \mathrm{MoS}_{\mathrm{x}}$ thickness). Shown are the relative atomic concentrations for $\mathrm{Mo}, \mathrm{S}, \mathrm{Sb}, \mathrm{Se}$ and $\mathrm{O}$. 

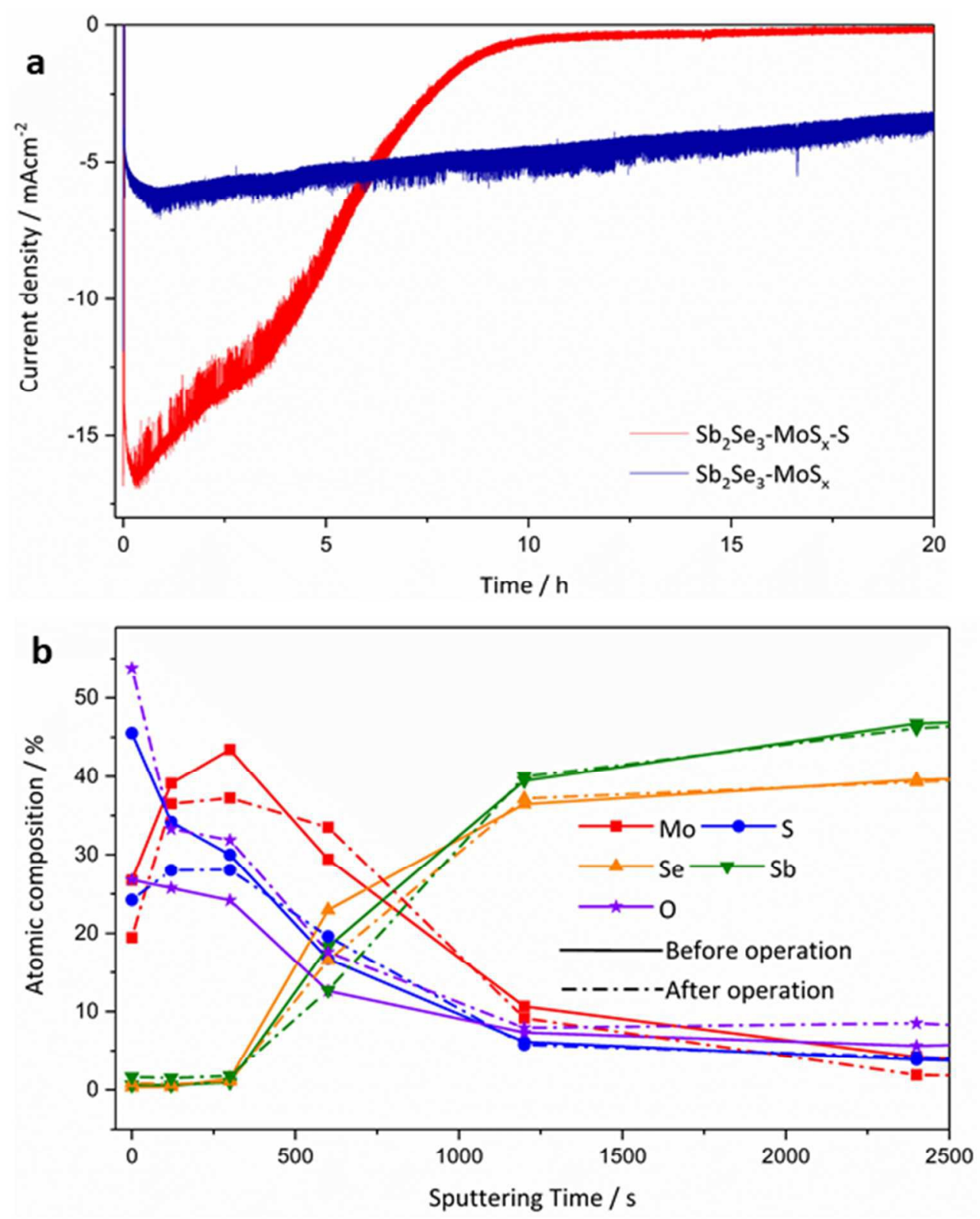

Figure 4. a Current density vs time plots for $\mathrm{Sb}_{2} \mathrm{Se}_{3}-\mathrm{MoS}_{\mathrm{x}}$ and $\mathrm{Sb}_{2} \mathrm{Se}_{3}-\mathrm{MoS}_{\mathrm{x}}-\mathrm{S}\left(\sim 30 \mathrm{~nm} \mathrm{MoS} \mathrm{X}_{\mathrm{x}}\right.$ thickness) in $1 \mathrm{M} \mathrm{H}_{2} \mathrm{SO}_{4}$ at $0 \mathrm{~V}$ vs RHE at 1 sun illumination $\left(100 \mathrm{~mW} \mathrm{~cm}{ }^{-2}\right)$. b XPS depth profile of $\mathrm{Sb}_{2} \mathrm{Se}_{3}-\mathrm{MoS}_{\mathrm{x}}$ before (as deposited) and after $20 \mathrm{~h}$ of stability measurement ( $30 \mathrm{~nm}$ $\mathrm{MoS}_{\mathrm{x}}$ thickness). Shown are the relative atomic concentrations of Mo, S, Sb, Se, and O. 
a

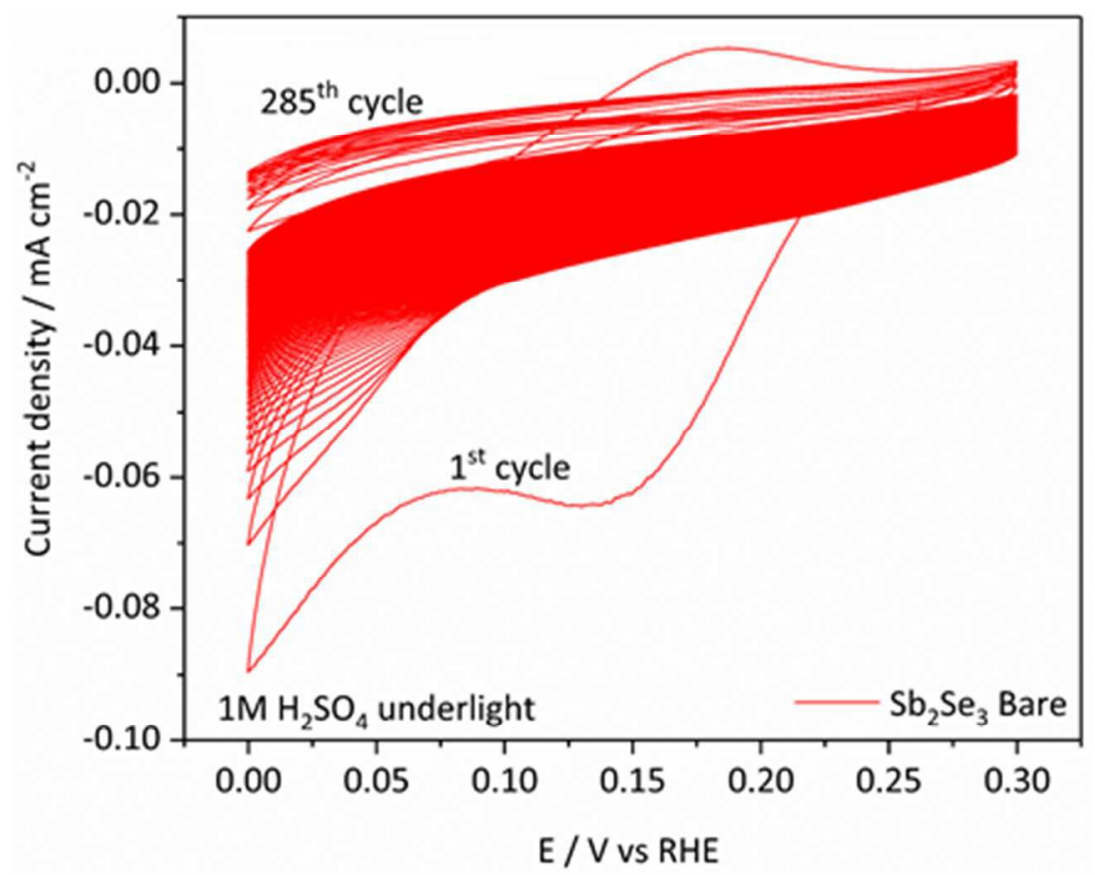

b

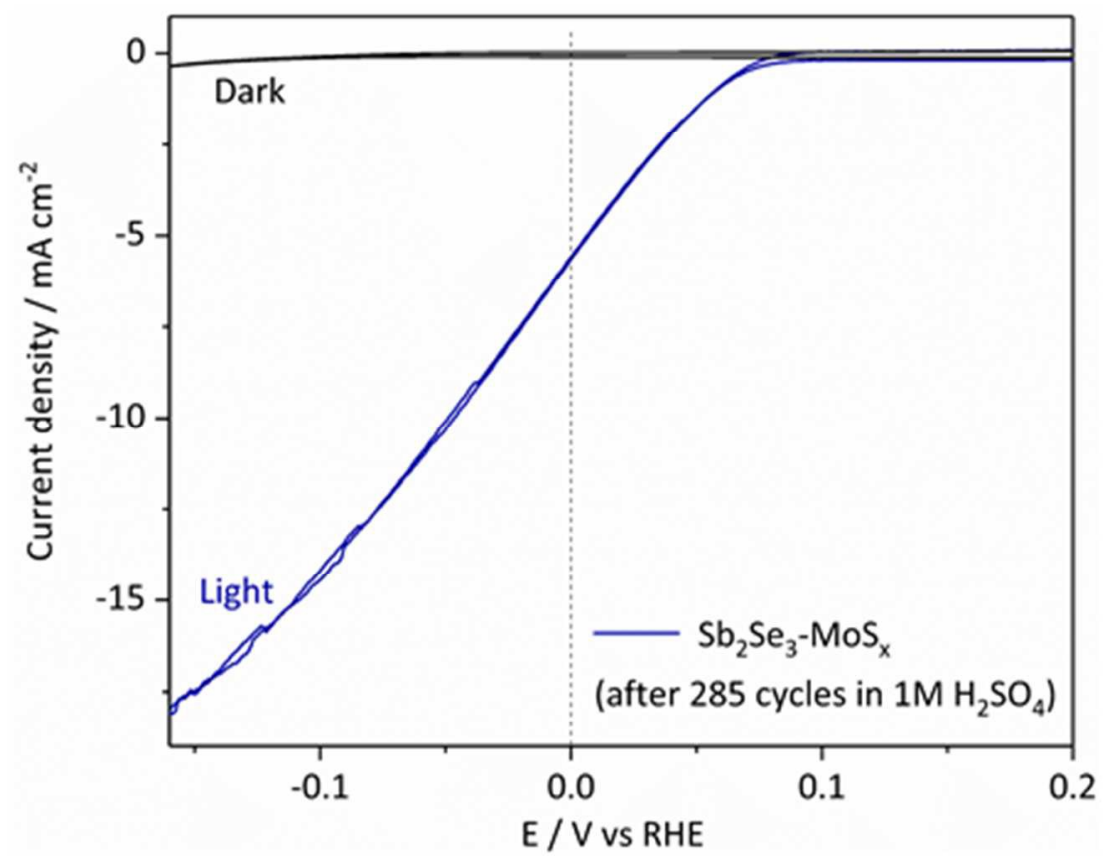

Figure 5. a $\mathrm{CV}$ of a bare $\mathrm{Sb}_{2} \mathrm{Se}_{3}$ thin film (without $\mathrm{MoS}_{\mathrm{x}}$ catalyst) in $1 \mathrm{M} \mathrm{H}_{2} \mathrm{SO}_{4}$ under 1 sun illumination $\left(100 \mathrm{~mW} \mathrm{~cm}^{-2}\right)$. The sweep rate was $10 \mathrm{mV} \mathrm{s}^{-1}$ and the total experiment time was 4.75 h. b Current density vs potential plots of a $\mathrm{Sb}_{2} \mathrm{Se}_{3}-\mathrm{MoS}_{\mathrm{x}}$ photocathode prepared after 285 $\mathrm{CV}$ cycles of bare $\mathrm{Sb}_{2} \mathrm{Se}_{3}$ in $1 \mathrm{M} \mathrm{H}_{2} \mathrm{SO}_{4}$ under 1 sun illumination. 


\section{Table of contents}
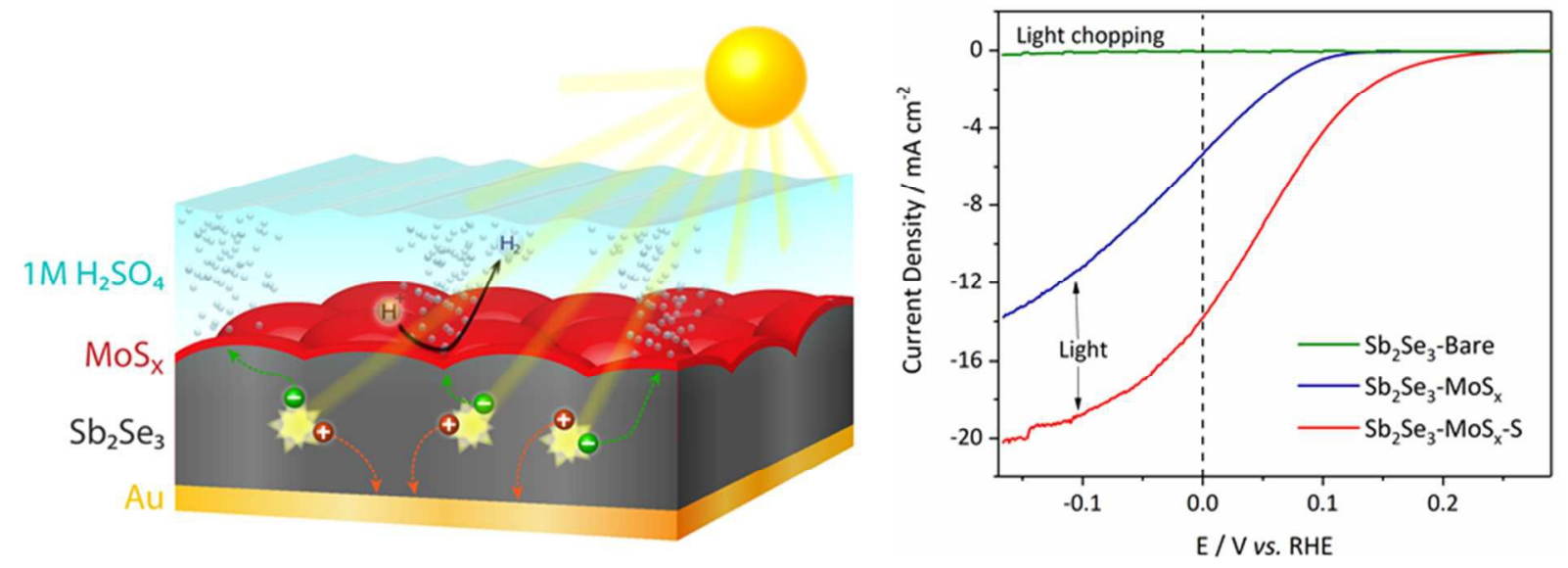

A highly efficient $\mathrm{Sb}_{2} \mathrm{Se}_{3}$ photocathode is resistant to photocorrosion in strongly acid media without protective overlayers. 